\title{
PREDIKSI PEMILIHAN JURUSAN DIPERGURUAN TINGGI
}

\author{
${ }^{(1)}$ Dian Agustini, ${ }^{(2)}$ Muthia Farida, ${ }^{(3)}$ Auliya Rahman \\ ${ }^{(1)(2)(3)}$ Fakultas Teknologi Informasi, Universitas Islam Kalimantan MAB \\ Jl. Adhiyaksa No. 2 Kayu Tangi, Banjarmasin \\ Email:dian.da989@gmail.com,muthiafarida59@yahoo.co.id, \\ auliyarahmankom@gmail.com
}

\begin{abstract}
The education sector is one of the fields that gets the most attention from the government, especially when graduating from high school students. It is expected that these graduates will continue to pursue higher education. Various information about majors in universities have been widely available but have not been able to meet the needs of prospective students. There are three main problems experienced by prospective students, namely limited knowledge of the majors to be followed, limited information available, and limited quantitative recommendations that can be used by prospective students.

This study tries to overcome these problems by producing predictions of departmental recommendations using the Naive Bayes algorithm and incorporating criteria that influence the selection of majors in the form of abilities, interests, and also preferences for certain fields. An approach to user preferences is used so that the recommendations approach the desired results. This is done by giving the criteria weighting to the user.
\end{abstract}

Keywords: Data Mining, Predictions, Universities, Naive Bayes

\section{PENDAHULUAN}

Semakin tinggi kesadaran siswa lulusan SMA untuk melanjutkan pendidikan berdampak pada persaingan ketat untuk dapat diterima di suatu perguruan tinggi. Akan tetapi, masih saja terdapat calon mahasiswa yang memilih jurusan yang kurang tepat. Ketidaksesuaian dalam pemilihan jurusan akan menyebabkan calon mahasiswa tidak memiliki semangat untuk belajar, bahkan dapat kehilangan motivasi untuk melanjutkan pendidikannya di perguruan tinggi. Banyak mahasiswa yang mengalami kegagalan di perguruan tinggi hanya disebabkan karena mahasiswa tersebut memilih jurusan berdasarkan reputasi atau mengikuti pilihan teman-temannya, sehingga jurusan yang dipilih tidak sesuai dengan kemampuan dan bakat yang dimiliki.

Selain itu, terdapat beberapa pendapat yang dapat mempengaruhi keputusan calon mahasiswa, yaitu pendapat dari orang tua, teman atau figur-figur yang diidolakan. Berdasarkan pendapat tersebut dan tanpa menelaah kemampuannya, calon mahasiswa dapat membuat keputusan yang sangat bertolak belakang dengan minta dan bakatnya. Beragam informasi mengenai jurusan perguruan tinggi telah banyak tersedia di media cetak maupun di internet sehingga memberikan kemudahan untuk mendapatkan informasi tersebut. Akan tetapi, informasi yang tersedia hanya memberikan penjelasan secara umum, spserti : profil, biaya, lokasi, dan informasi umum lainnya. Informasi 
tersebut belumsepeneuhnya membantu memberi masukan mengenai jurusan yang sesuai dengan kemampuan, minat dan kesukaan calon mahasiswanya.

Kriteria yang digunakan untuk menghasilkan prediksi pemilihan jurusan berupa kemampuan dan bakat siswa masih kurang mewakili kondisi calon mahasiswa. Sebagai contoh, siswa A memiliki bakat dan kemampuan di bidang komunikasi, akan tetapi siswa tersebut tidak ingin mengambil jurusan komunikasi. Hal yang mungkin terjadi ketika siswa A tetap mengambil jurusan Komunikasi adalah kemampuan siswa di bidang komunikasi semakin meningkat dan memiliki prestasi serta IPK yang tinggi. Akan tetapi siswa A menjalani perkuliahan dengan terpaksa jika karena bukan didasarkan atas keinginannya sendiri. Jika hal ini di biarkan terus menerus dapat berakibat hal-hal yang kurang baik. Contoh berikutnya adalah siswa B memiliki ketertarikan di bidang hukum dan mengambil jurusan hukum, padahal kemampuan dan minatnya tidak mengarahkan siswa B untuk mengambil jurusan hukum. Maka kemungkinan yang dapat terjadi adalah siswa B akan mengalami kesulitan ketika mengikuti perkuliahan yang diberikan. Dari kedua contoh tersebut dapat diambil kesimpulan bahwa untuk membuat keputusan pemilihan jurusan, selain mempertimbangkan kemampuan, minat, dan abakat calon mahasiswa juga perlu mempertimbangkan keinginan pribadi calon mahasiswa sehingga didapatkan hasil prediksi yang sesuai dan diinginkan.

\section{METODE PENELITIAN}

Penelitian ini dilakukan berdasarkan beberapa tahapan yang harus dikerjakan agar hasil akhir penerapan metode prediksi dengan algoritma Naive Bayes dapat bermanfaat sebagai media informasi yang mudah dipahami, maka tahapan penelitian sebagai berikut :
1. Identifikasi masalah yang akan diteliti, pada penelitian menganalisa informasi terhadap pemilihan jurusan serta penerapannya pada metode data mining menggunakan algoritma Naive Bayes dan K-NN.

2. Analisa literatur, buku, jurnal serta perangkat pendukung penelitian seperti spesifikasi hardware yang mumpuni untuk proses pengolahan data serta software yang berlisensi untuk memudahkan pengolahan laporan serta akses terhadap jurnaljurnal terkait.

3. Menguji data training dan data testing berupa NIS, Jenis kelamin, nilai semester 1 dan 2 untuk jurusan IPA serta rekomendasi.

4. Menguji aplikasi dengan menggunakan data yang telah dipreprosessing.

5. Membuat laporan dan membuat kesimpulan dari kelas-kelas yang diprediksi.

Langkah awal penelitian :

1. Menentukan karakteristik data yang akan di proses serta menetukan label sebagai kelas.

2. Menentukan algoritma prediksi yang digunakan

3. Menentukan software pendukung yang digunakan

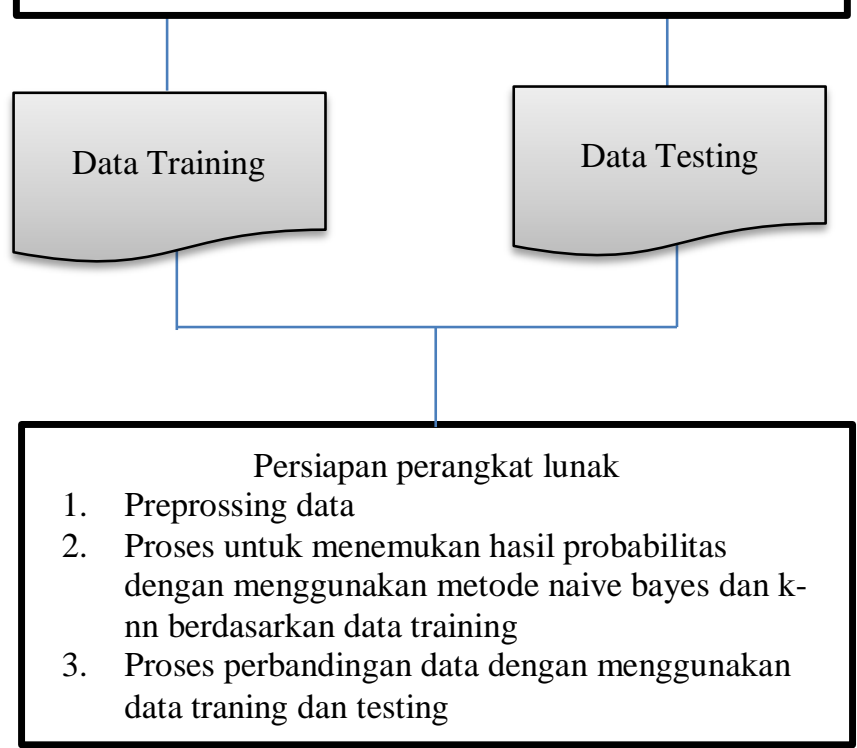




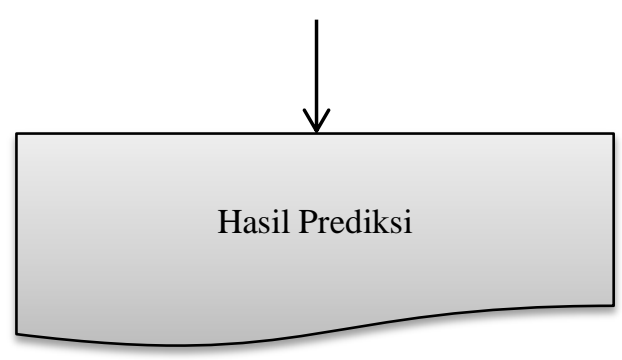

Gambar 2. Rancangan Penelitian

\section{HASIL DAN PEMBAHASAN}

SMA Negeri 7 Banjarmasin adalah salah satu sekolah negeri unggulan di banjarmasin. Berlokasi di Jl. Dharma Praja V No. 47, Pemurus Luar Kecamatan banjrmasin Timur. Sekolah ini didirikan pada tahun 1997 hingga tahun 2018 dengan program jurusan /peminatan MIPA dan IPS. Berdasarkan data terakhir pada tahun 2018, jumlah siswa yang ada di SMAN 7 Banjarmasin sebanyak 180 siswa dikelas XII jurusan IPA.

Berikut tabel distribusi jumlah siswa untuk tiap kelas di sman 7 banjarmasin Tabel 1. Jumlah siswa per Kelas

\begin{tabular}{|c|c|c|c|c|}
\hline NO & $\begin{array}{c}\text { KELAS } \\
\text { (IX) }\end{array}$ & LK & PR & JUMLAH \\
\hline 1 & IPA 1 & 15 & 21 & 36 \\
\hline 2 & IPA 2 & 15 & 21 & 36 \\
\hline 3 & IPA 3 & 16 & 20 & 36 \\
\hline 4 & IPA 4 & 17 & 19 & 36 \\
\hline 5 & IPA 5 & 17 & 19 & 36 \\
\hline
\end{tabular}

Untuk mendapatkan input yang baik dari teknik data mining, dilakukan preprocessing terhadap data yang akan digunakan. Preprocessing data merupakan tahap prapemrosesan. Sebelum proses data mining dapat dilaksanakan, perlu dilakukan proses cleaning (pembersihan) pada data. Dalam kasus ini, data yang diambil sebanyak 180 data siswa kelas XII jurusan IPA tahun ajaran 2017/2018 dari SMAN 7 Banjarmasin. Atribut yang digunakan pada penelitian ini berupa NIS, Jenis Kelamin, Minat Jurusan (FKM dan Ekonomi), Nilai Semester 1 dan 2 untu mata pelajaran : matematika, kimia, biologi dan fisika serta rekomedasi dari hasil prediksi.

Hasil Eksperimen dan Pengujian Model

Semster 1.

Tabel 2. Hasil Modifikasi Data

\begin{tabular}{|r|l|r|r|r|r|r|}
\hline nis & l/p & \multicolumn{1}{l|}{ Jur } & \multicolumn{1}{l|}{ mat } & \multicolumn{1}{l|}{ fis } & \multicolumn{1}{l|}{ kim } & \multicolumn{1}{l|}{ bio } \\
\hline 10754 & $\mathrm{P}$ & 1 & 78 & 75 & 77 & 78 \\
\hline 10756 & $\mathrm{~L}$ & 2 & 77 & 76 & 75 & 83 \\
\hline 10764 & $\mathrm{P}$ & 1 & 78 & 79 & 80 & 76 \\
\hline 10738 & $\mathrm{~L}$ & 1 & 78 & 79 & 83 & 81 \\
\hline 10786 & $\mathrm{P}$ & 1 & 81 & 80 & 77 & 78 \\
\hline 10793 & $\mathrm{P}$ & 1 & 78 & 77 & 75 & 75 \\
\hline 10800 & $\mathrm{P}$ & 1 & 79 & 77 & 78 & 75 \\
\hline 10802 & $\mathrm{P}$ & 1 & 81 & 81 & 77 & 77 \\
\hline 10805 & $\mathrm{P}$ & 1 & 78 & 76 & 78 & 75 \\
\hline 10810 & $\mathrm{~L}$ & 1 & 80 & 77 & 77 & 75 \\
\hline 10814 & $\mathrm{P}$ & 1 & 79 & 80 & 77 & 87 \\
\hline
\end{tabular}

Data sampel terdiri dari dari atribut NIS, Jenisk Kelamin, Angket Minat (FKM dan FEKON), Psikotes IQ, Nilai Semester 1 \& 2 dengan Mata Pelajaran : Matematika, Fisika, Kimia, Biologi, dan Rata-Rata Semester $1 \& 2$.

Untuk pengujiannya menggunakan Software data mining yaitu RapidMiner, untuk uji pertama melalui data sampel yaitu nilai siswa kelas XII IPA Semester 1.

Untuk pengujiannya menggunakan Software data mining yaitu RapidMiner, untuk uji kedua melalui data sampel yaitu nilai siswa kelas XII IPA Semester 2.

Lalu selanjutnya dilakukan uji ketiga dengan menggunakan data sampel yaitu nilai rata-rata siswa kelas XII IPA Semester 1 dan 2.

Dari hasil tersebut maka didapatkan data-data dalam 3 tabel, yang pertama adalah Tabel Perbandingan Algoritma K-NN dengan Naive Bayes untuk Nilai Semester 1, Tabel Perbandingan Algoritma K-NN dengan Naive Bayes untuk Nilai Semester 2, dan Tabel Perbandingan Algoritma K-NN dengan Naive Bayes untuk nilai Semester 1 dan 2 yang bisa dilihat pada tabel berikut : 
Tabel 3. Perbandingan Nilai Semester 1

\begin{tabular}{|l|l|l|}
\hline $\begin{array}{l}\text { Rata-Rata Nilai } \\
\text { Semester 1 }\end{array}$ & K-NN (\%) & Naive Bayes (\%) \\
\hline Akurasi (\%) & 82,39 & 85,80 \\
\hline Presicion (\%) & 74,51 & 89,74 \\
\hline Recall (\%) & 67,86 & 62,74 \\
\hline
\end{tabular}

Tabel 4. Perbandingan Nilai Semester 2

\begin{tabular}{|l|l|l|}
\hline Nilai Semester 2 & K-NN (\%) & Naive Bayes (\%) \\
\hline Akurasi (\%) & 82,39 & 85,80 \\
\hline Presicion (\%) & 74,51 & 89,74 \\
\hline Recall (\%) & 67,86 & 62,74 \\
\hline
\end{tabular}

Tabel 5. Perbandingan Nilai Semester $1 \& 2$

\begin{tabular}{|l|l|l|}
\hline $\begin{array}{l}\text { Rata-Rata Nilai } \\
\text { Semester 1\& 2 }\end{array}$ & K-NN (\%) & Naive Bayes (\%) \\
\hline Akurasi (\%) & $\mathbf{7 2 , 3}$ & 90,34 \\
\hline Presicion (\%) & 57,14 & 76,71 \\
\hline Recall (\%) & 57,14 & 100 \\
\hline
\end{tabular}

\section{KESIMPULAN}

Dari hasil uji coba yang telah dilakukan, maka didapatkan kesimpulan bahwa Algoritma Naive Bayes memiliki hasil akurasi yang lebih tinggi untuk memprediksi pemilihan jurusan diperguruan tinggi yaitu sebesar 90,34\% daripada menggunakan algoritma K-NN yang hasil akurasinya adalah $72,3 \%$.

\section{REFERENSI}

[1] A.M Pujiati, S. A., \& Astuti. (2008). Sistem Pengambilan Keputusan Jurusan Di Perguruan Tinggi. Surabaya.

[2] A.R Aslam, M. Z. (2011). A Proposed Decison Tree Support System/Expert System for Guiding Fresh Student in Selecting a Faculty in Gomal University. Ind. Eng. Lett ISSN 2224-6096 ISSN 2225-0581, 33-41.

[3] Bustami. (128-146). Penerapan Algoritma Naive Bayes Untuk Mengklasifikasi Data Nasabah Asuransi. TECHSI:Jurnal Penelitian Teknik Informatika.

[4] Forman, G., \& Cohen, I. (2004). Comparison of Classifiers Given Little Training. Knowledge
Discovery in Databases: PKDD 2004, (pp. 161-172).

[5] Gindo, A., \& Hari, B. (2012). Pengukuran Partikel Udara Ambien (Tsp, PM10, PM2, 5) Di Sekitar Calon Lokasi Pltn Semanjung Lemahabang. Prosiding seminar nasional teknologi pengolahan limbah VI (pp. 220-227). Pusat Penelitian Ilmu Pengetahuan dan Teknologi - RISTEK.

[6] Huboyo, H. S., \& Sutrisno, E. (2009). Analisis Konsentrasi Particulate Matter 10 (PM10) pada Udara Diluar Ruang (Studi Kasus : Stasiun Tawang - Semarang). TEKNIK, 30(1), 44-48.

[7] Liu, C., Fuertes, E., Flexeder, C., Hofbauer, L. C., Berdel, D., Hoffmann, B., . . . Heinrich, J. (2015). Associations betweens Ambient Air Pollution and Bone Turnover Markers in 10-year old children: Result from the GINIplus and LISAplus Studies. International Journal of Hygiene and Environmental Health, 218, 58-65.

[8] SL, T., Ip, W., \& Tsang, A. H. (2011). Is Naive Bayes a Good Classifier for Document Classification. International Journal of Software Engineering and Its Applications 5.3, 37-46.

[9] Stern, M. K., Beck, J. E., \& Woolf, B. P. (1999). Naïve Bayes Classifiers for User Modeling. Proceedings of the Conference on User Modeling.

[10] World Health Organization. (n.d.). Public health, environmental and social determinants of health (PHE). Retrieved 4 10, 2016, from

[11] World Health Organization: http://www.who.int/phe/air_quality_ q\&a 